Claudia Georgi Liveness on Stage 


\section{CDE Studies}

Edited by

Martin Middeke

Volume 25 


\section{Claudia Georgi}

\section{Liveness on Stage}

Intermedial Challenges in Contemporary

British Theatre and Performance 
ISBN 978-3-11-034590-2

e-ISBN 978-3-11-034653-4

ISSN 2194-9069

\section{Library of Congress Cataloging-in-Publication Data}

A CIP catalog record for this book has been applied for at the Library of Congress.

\section{Bibliographic information published by the Deutsche Nationalbibliothek}

The Deutsche Nationalbibliothek lists this publication in the Deutsche Nationalbibliografie; detailed bibliographic data are available in the Internet at http://dnb.dnb.de.

(C) 2014 Walter de Gruyter GmbH, Berlin/Boston

Printing and binding: $\mathrm{CPI}$ books $\mathrm{GmbH}$, Leck

(2) Printed on acid-free paper

Printed in Germany

www.degruyter.com 